\title{
Wpływ gazu osłonowego na emisję zanieczyszczeń podczas lutospawania łukowego blach stalowych pokrytych powłokami ochronnymi
}

\author{
Shielding gas influence on pollutants emission \\ during arc weld brazing of steel sheets \\ with protective coatings
}

\section{Streszczenie}

W artykule przedstawiono wyniki badań wielkości emisji zanieczyszczeń pyłowych i gazowych powstających przy lutospawaniu łukowym metodami MIG/MAG. Badania przeprowadzono dla blach stalowych z powłoką cynkową oraz powłoką ze stopu cynku i żelaza. Na osłonę łuku zastosowano argon oraz mieszaniny gazowe dwuskładnikowe typu $\mathrm{Ar}+\mathrm{O}_{2}$, $\mathrm{Ar}+\mathrm{CO}_{2}, \mathrm{Ar}+\mathrm{H}_{2}$ i trójskładnikowe $\mathrm{Ar}+\mathrm{CO}_{2}+\mathrm{H}_{2}$. W analizie wyników badań przedstawiono wpływ składu gazu osłonowego na wielkość emisji pyłu całkowitego, tlenków azotu i tlenku węgla oraz na skład chemiczny zanieczyszczeń pyłowych.

Słowa kluczowe: lutospawanie; emisja zanieczyszczeń; blachy z powłokami ochronnymi; gazy osłonowe; skład chemiczny pyłu

\begin{abstract}
The results of research into the fume and gas emission during MIG/MAG arc weld brazing are presented in the article. Research was conducted for hot - dip coated steel sheets with zinc and zinc and iron alloy coatings. Arc shielding gases applied were $\mathrm{Ar}, \mathrm{Ar}+\mathrm{O}_{2}, \mathrm{Ar}+\mathrm{CO}_{2}, \mathrm{Ar}+\mathrm{H}_{2}$ and $\mathrm{Ar}+\mathrm{CO}_{2}+\mathrm{H}_{2}$ gas mixtures. The analysis of the results presents the influence of composition of shielding gas effect on the emission rate of total fume, nitrogen oxides and carbon monoxide and the chemical composition of welding fume.
\end{abstract}

Keywords: weld brazing; pollutants emission; protective coated sheet; shielding gases; chemical composition of welding fume

\section{Wprowadzenie}

Procesy lutospawania związane są z wydzielaniem się do środowiska zanieczyszczeń w postaci dymu spawalniczego. Dym (aerozol dwufazowy kondensacyjny) jest mieszaniną drobno dyspersyjnych cząstek stałych (pyłu) oraz różnych gazów, głównie tlenków azotu i tlenku węgla, które stanowią fazę rozpraszającą aerozolu. Skład chemiczny pyłu przy lutospawaniu jest odmienny od składu chemicznego pyłu przy procesach spawania i zależy od składu drutu elektrodowego, rodzaju oraz grubości powłoki ochronnej i w znikomym procencie od składu chemicznego materiału rodzimego. Lutospawanie blach stalowych z powłokami cynkowymi wiąże się ze znaczną emisją związków cynku. Skład chemiczny spoiw stosowanych $\mathrm{w}$ procesach lutospawania łukowego powoduje, że $\mathrm{w}$ pyle występują związki miedzi oraz manganu. Związki cynku mogą być przyczyną gorączki metalicznej - choroby zawodowej, której objawy przypominają grypę i ustępują po kilku dniach [1]. Długotrwałe narażenie pracowników na oddziaływanie dymu spawalniczego powoduje różnego rodzaju schorzenia układu oddechowego.

W badaniach ukierunkowanych na poszukiwanie metod ograniczania emisji dymu przy procesach spawalniczych, możliwości doboru gazów osłonowych o różnym składzie chemicznym stanowią jedną z ważniejszych dróg do zmniejszania zagrożenia środowiska pracy czynnikami chemicznymi. Głównym celem badań, które przedstawiono w artykule było wyznaczenie korelacji pomiędzy składem gazu osłonowego a wielkością emisji zanieczyszczeń oraz składem chemicznym pyłu z procesu lutospawania łukowego metodą MIG/MAG blach stalowych z powłokami ochronnymi $[2,3]$.

\section{Zakres badań}

Badania prowadzono dla sześciu gazów osłonowych, zastosowano argon $\mathrm{i}$ jego mieszaniny $\mathrm{z}$ tlenem $\left(\mathrm{Ar}+2 \% \mathrm{O}_{2}\right)$, dwutlenkiem węgla $\left(\mathrm{Ar}+2 \% \mathrm{CO}_{2}\right)$, wodorem $\left(\mathrm{Ar}+2 \% \mathrm{H}_{2}\right)$ oraz $\mathrm{z}$ dwutlenkiem węgla i wodorem $\left(\mathrm{Ar}+2 \% \mathrm{CO}_{2}+1 \% \mathrm{H}_{2}\right.$ i $\mathrm{Ar}+3 \% \mathrm{CO}_{2}+1 \% \mathrm{H}_{2}$ ). Mieszaniny gazowe o takim składzie uznawane są za najkorzystniejsze technicznie osłony gazowe do zastosowania zwłaszcza w procesach lutospawania metodą MIG/MAG [4,5]. Materiał podstawowy wykorzystany $\mathrm{w}$ badaniach stanowiła stal ocynkowana w gat. DX

Dr inż. Jolanta Matusiak, mgr inż. Joanna Wyciślik - Instytut Spawalnictwa, Gliwice.

Autor korespondencyjny/Corresponding author: jolanta.matusiak@is.gliwice.pl 
54D Z100MBO i DX 54D ZF100RBO. Zastosowano blachy stalowe ocynkowane zanurzeniowo (ogniowo) z powłoką cynkową typu Z100MBO (powłoka cynkowa, podwyższona jakość powierzchni, oliwiona, grubość powłoki 5-12 $\mu \mathrm{m}$ ) oraz z powłoką ze stopu cynku i żelaza typu ZF100RBO (powłoka ze stopu cynku i żelaza, podwyższona jakość powierzchni, oliwiona, grubość powłoki 5-12 $\mu \mathrm{m})$. W trakcie badań zastosowano jeden stały dla wszystkich gazów i wybranych blach stalowych zestaw parametrów technologicznych lutospawania. Wykaz gazów osłonowych i parametrów technologicznych do badań emisji zanieczyszczeń przedstawiono w tablicy I. Do lutospawania zastosowano spoiwo w postaci drutu litego w gatunku CuSi3Mn, o średnicy $1 \mathrm{~mm}$, spoiwo zawiera: $2,80 \div 2,95 \% \mathrm{Si}, 0,75 \div 0,95 \% \mathrm{Mn}$, reszta $\mathrm{Cu}$.

Badania wielkości emisji pyłu i gazów wykonano na spawalniczym stanowisku doświadczalnym wyposażonym w komorę pyłową zabezpieczającą przed wypływem zanieczyszczeń na zewnątrz. Do pobierania próbek pyłu w celu określenia emisji zastosowano metodę grawimetryczną. Badania emisji gazów przy lutospawaniu prowadzone były metodą bezpośrednią, czyli z zastosowaniem analizatora Testo-350 z odczytem bezpośrednim gazów (NO, $\mathrm{NO}_{2}, \mathrm{CO}$ ) oraz temperatury. Identyfikację fazową i ilościową analizę fazową pyłu wykonano z wykorzystaniem dyfraktometru rentgenowskiego Empyrean stosując promieniowanie kobaltu w konfiguracji z detektorem Pixcel. Podstawą do identyfikacji składników fazowych była baza International Centre for Diffraction Data PDF-4 (2011).

\section{Wpływ składu gazu osłonowego na wielkość emisji zanieczyszczeń}

Badania wykazały, że skład gazu osłonowego wpływa na wielkość emisji pyłu przy lutospawaniu łukowym metodą MIG/MAG. Wśród badanych sześciu gazów osłonowych stwierdzono, że największa emisja pyłu całkowitego związana jest z zastosowaniem argonu na osłonę łuku spawalniczego. Prawidłowość powyższą wykazano dla obydwu gatunków materiałów podstawowych, tzn. blach stalowych z powłoką cynkową typu Z oraz typu ZF. Najkorzystniejsze w ograniczeniu wielkości emisji pyłu jest zastosowanie mieszanin trójskładnikowych. Mieszanina gazowa $\mathrm{Ar}+2 \% \mathrm{CO}_{2}+1 \% \mathrm{H}_{2}$ charakteryzowała się najmniejszą emisją pyłu całkowitego przy lutospawaniu MIG/MAG blach stalowych z powłokami. W porównaniu do lutospawania w osłonie $\mathrm{Ar}$, wprowadzenie mieszaniny $\mathrm{Ar}+2 \% \mathrm{CO}_{2}+1 \% \mathrm{H}_{2}$ spowodowało ograniczenie wielkości emisji pyłu w całym badanym zakresie prądowo-napięciowym średnio o 35\% dla blachy z powłoką cynkową typu Z i średnio o $50 \%$ dla blachy z powłoką stopową cynk i żelazo typ ZF. Kolejna trójskładnikowa mieszanina gazowa $\mathrm{Ar}+3 \% \mathrm{CO}_{2}+1 \% \mathrm{H}_{2}$ zastosowana na osłonę łuku wykazała mniej pozytywne wyniki w aspekcie ograniczenia wielkości emisji pyłu całkowitego. W porównaniu do lutospawania w osłonie Ar, wprowadzenie mieszaniny $\mathrm{Ar}+3 \% \mathrm{CO}_{2}+1 \% \mathrm{H}_{2}$ spowodowało redukcję wielkości emisji pyłu w całym badanym zakresie prądowo-napięciowym średnio o ok. 30\% dla blachy z powłoką cynkową typu Z i powłoką typu ZF. Wprowadzenie na osłonę łuku mieszanin gazowych dwuskładnikowych powoduje również ograniczenie wielkości emisji pyłu. Dla mieszaniny $\mathrm{Ar}+2 \% \mathrm{O}_{2}$ wykazano, że w porównaniu do lutospawania w osłonie argonu, emisja pyłu uległa ograniczeniu o $25 \%$ dla blachy stalowej z powłoką typu Z i o $22 \%$ dla powłoki typu ZF. Dla mieszaniny $\mathrm{Ar}+2 \% \mathrm{CO}_{2}$ wykazano, że emisja pyłu całkowitego uległa ograniczeniu o ok. $33 \%$ dla blachy z powłoką typu ZF i ok. $25 \%$ dla powłoki typu Z. W badaniach wielkości emisji pyłu na osłonę łuku zastosowano również mieszaninę o składzie $\mathrm{Ar}+2 \% \mathrm{H}_{2}$. W porównaniu do lutospawania w osłonie $\mathrm{Ar}$, wprowadzenie mieszaniny $\mathrm{Ar}+2 \% \mathrm{H}_{2}$ spowodowało ograniczenie wielkości emisji pyłu w całym badanym zakresie parametrów prądowo-napięciowych o 30\% dla blachy stalowej z powłoką cynkową typu Z i typ ZF. Zależności pomiędzy składem gazu osłonowego a wielkością emisji pyłu całkowitego dla badanego zakresu parametrów prądowo-napięciowych przedstawiono na rysunku 1.

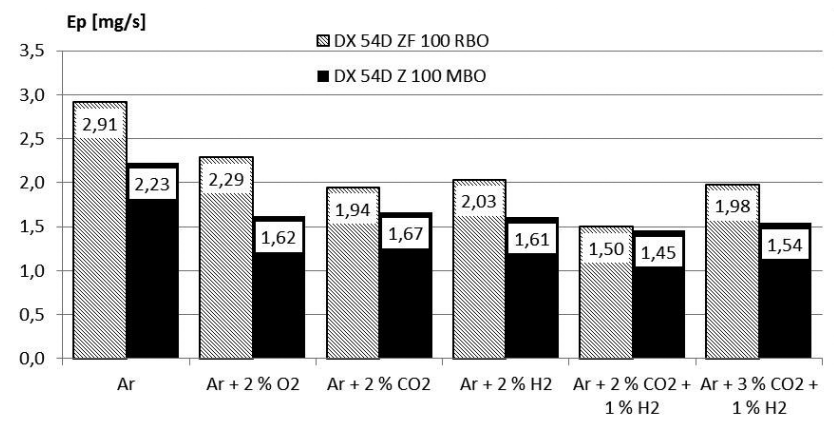

Rys. 1. Wpływ składu gazu osłonowego na wielkość emisji pyłu podczas lutospawania MIG/MAG blach stalowych z powłokami ochronnymi [2]. Zakres parametrów technologicznych: natężenie prądu spawania: $70 \mathrm{~A} \div 130 \mathrm{~A}$, napięcie łuku: $13,7 \mathrm{~V} \div 17,7 \mathrm{~V}$, prędkość podawania drutu: $3,5 \div 7,0[\mathrm{~m} / \mathrm{min}]$, prędkość spawania: $190 \div 620[\mathrm{~mm} / \mathrm{min}]$

Fig. 1. Influence of shielding gas composition on fume emission during MIG/MAG weld brazing of steel sheets with protective coatings. (I - welding current, $U-$ arc voltage, $V_{w}$ - wire feed rate, $V_{\text {ws }}$ - welding speed, $I=70 \div 130 \mathrm{~A} ; U=13,7 \div 17,7 \mathrm{~V} ; V_{w}=3,5 \div 7,0 \mathrm{~m} / \mathrm{min}$; $\left.V_{\text {ws }}=190 \div 620 \mathrm{~mm} / \mathrm{min}\right)$

Tablica I. Zestawienie gazów osłonowych i parametrów technologicznych do badania emisji zanieczyszczeń [2] Table I. Shielding gases and technological parameters for research into emission of pollutants [2]

\begin{tabular}{|c|c|c|c|c|c|c|c|c|c|c|}
\hline \multirow{2}{*}{ Gatunek stali } & \multirow{2}{*}{\multicolumn{6}{|c|}{ Gaz osłonowy }} & \multicolumn{4}{|c|}{ Parametry technologiczne procesu } \\
\hline & & & & & & & \multirow{2}{*}{$\frac{\mathrm{I}[\mathrm{A}]}{70}$} & \multirow{2}{*}{$\begin{array}{l}\mathbf{U}[\mathbf{V}] \\
13,7\end{array}$} & \multirow{2}{*}{$\frac{\mathrm{Vdr}[\mathrm{m} / \mathrm{min}]}{3,5}$} & \multirow{2}{*}{$\frac{\text { Vsp }[\mathrm{mm} / \mathrm{min}]}{190}$} \\
\hline \multirow{3}{*}{$\begin{array}{c}\text { DX 54D ZF } \\
100 \text { RBO }\end{array}$} & \multirow{6}{*}{ 这 } & \multirow{6}{*}{$\begin{array}{l}\stackrel{0}{ } \\
\stackrel{\circ}{+} \\
+ \\
\dot{<}\end{array}$} & \multirow{6}{*}{$\begin{array}{l}\text { O } \\
\text { Оे } \\
\text { Nे } \\
+ \\
\dot{<}\end{array}$} & \multirow{6}{*}{$\begin{array}{l}\frac{1}{2} \\
\stackrel{े}{\circ} \\
+ \\
+ \\
\frac{1}{<}\end{array}$} & \multirow{6}{*}{ 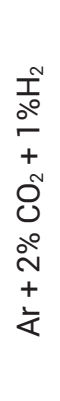 } & \multirow{6}{*}{ 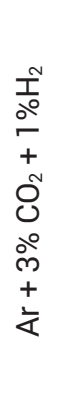 } & & & & \\
\hline & & & & & & & 100 & 16,7 & 5,3 & 320 \\
\hline & & & & & & & 130 & 17,7 & 7,0 & 620 \\
\hline \multirow{3}{*}{$\begin{array}{l}\text { DX 54D Z } \\
100 \text { MBO }\end{array}$} & & & & & & & 70 & 13,7 & 3,5 & 190 \\
\hline & & & & & & & 100 & 16,7 & 5,3 & 320 \\
\hline & & & & & & & 130 & 17,7 & 7,0 & 620 \\
\hline
\end{tabular}

I [A] - prąd spawania, U [V]- napięcie łuku, Vdr [m/min]- prędkość podawania drutu, Vsp [mm/min]- prędkość spawania 
Skład gazu osłonowego przy lutospawaniu łukowym metodą MIG/MAG wpływa także na wielkość emisji tlenków azotu. Wśród przebadanych sześciu różnych gazów osłonowych największa emisja $\mathrm{NO}_{x}$ wystąpiła przy zastosowaniu na osłonę łuku argonu oraz mieszanki $\mathrm{Ar}+2 \% \mathrm{O}_{2}$. Przy lutospawaniu blachy stalowej z powłoką cynkową typu Z największa emisja $\mathrm{NO}_{x}$ występuje przy zastosowaniu na osłonę łuku argonu, natomiast przy lutospawaniu blachy z powłoką typu ZF mieszanina $\mathrm{Ar}+2 \% \mathrm{O}_{2}$ powoduje największą emisję tlenków azotu. Z kolei mieszanina gazowa $\mathrm{Ar}+2 \% \mathrm{CO}_{2}$ charakteryzowała się najmniejszą emisją $\mathrm{NO}_{\mathrm{x}}$ przy lutospawaniu MIG/MAG blach stalowych z powłokami (rys. 2). W porównaniu do lutospawania w osłonie Ar, wprowadzenie tej mieszaniny spowodowało średnio 4,5-krotne ograniczenie wielkości emisji tlenków azotu dla blachy z powłoką cynkową typu Z i ponad 6,5-krotne dla blachy z powłoką typu ZF. Zastosowanie na osłonę łuku trójskładnikowych mieszanin gazowych $\mathrm{Ar}+\mathrm{CO}_{2}+\mathrm{H}_{2}$ również sprzyjało zmniejszeniu emisji $\mathrm{NO}_{\mathrm{x}} \mathrm{w}$ porównaniu do lutospawania w osłonie Ar. Wprowadzenie mieszaniny $\mathrm{Ar}+2 \% \mathrm{CO}_{2}+1 \% \mathrm{H}_{2}$ spowodowało ograniczenie wielkości emisji $\mathrm{NO}_{\mathrm{x}} \mathrm{w}$ całym badanym zakresie prądowo-napięciowym średnio o 34\% dla blachy z powłoką cynkową typ ZF i o ok. $16 \%$ dla blachy z powłoką typu Z. W przypadku lutospawania blachy stalowej z powłoką typu Z, wprowadzenie na osłonę łuku mieszaniny gazowej $\mathrm{Ar}+3 \% \mathrm{CO}_{2}+1 \% \mathrm{H}_{2}$ powoduje ponad 2-krotne ograniczenie emisji tlenków azotu w porównaniu do osłony argonowej.

Analiza wyników badań wykazała wpływ składu chemicznego gazu osłonowego na wielkość emisji tlenku węgla przy lutospawaniu łukowym MIG/MAG blach stalowych z powłokami ochronnymi. Zastosowanie na osłonę łuku mieszanin trójskładnikowych $\mathrm{Ar}+\mathrm{CO}_{2}+\mathrm{H}_{2}$ zwiększa emisję tlenku węgla ok. $25 \div 30-k r o t n i e ~ w$ porównaniu do emisji przy lutospawaniu w osłonie Ar. Duża emisja tlenku węgla dla mieszanin trójskładnikowych związana jest z zawartością w składzie $\mathrm{CO}_{2}$ na poziomie $2 \div 3 \%$. Jak wiadomo, głównym źródłem tlenku węgla przy spawaniu/lutospawaniu łukowym w osłonie gazowej jest dwutlenek węgla. W wyniku dysocjacji termicznej $\mathrm{CO}_{2}$ do środowiska wydzielany jest tlenek węgla, zgodnie z reakcją: $2 \mathrm{CO}_{2} \rightarrow 2 \mathrm{CO}+\mathrm{O}_{2}$. Mieszanina $\mathrm{Ar}+2 \% \mathrm{CO}_{2}$ również powoduje ok.10 $\div 15$-krotny wzrost emisji CO w porównaniu do osłony jednoskładnikowej- argonu. Zastosowanie przy lutospawaniu MIG/MAG gazu osłonowego $\mathrm{Ar}+2 \% \mathrm{H}_{2}$ zwiększa emisję tlenku węgla (podobnie

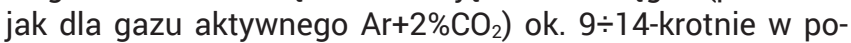
równaniu do emisji CO przy lutospawaniu w osłonie argonu. Najmniejsza emisja tlenku węgla występuje przy argonie i mieszaninie $\mathrm{Ar}+2 \% \mathrm{O}_{2}$, wielkość emisji $\mathrm{CO}$ dla tych dwóch gazów osłonowych jest bardzo zbliżona (rys. 3).

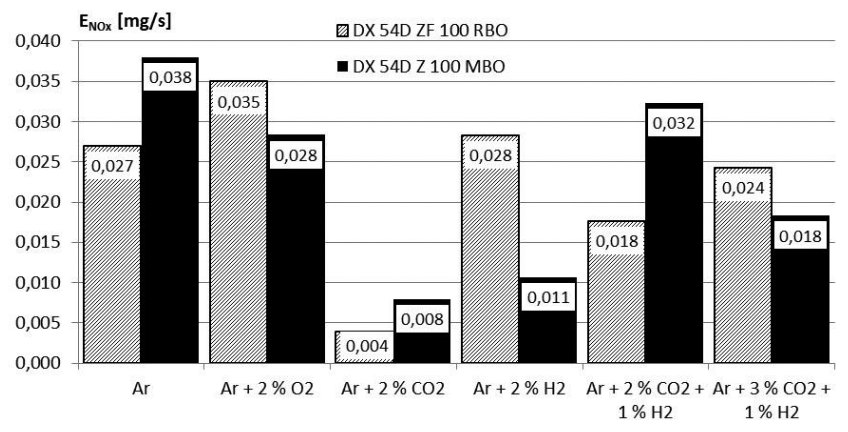

Rys. 2. Wpływ składu gazu osłonowego na wielkość emisji tlenków azotu podczas lutospawania MIG/MAG blach stalowych z powło-

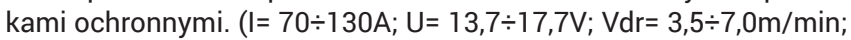
$V s p=190 \div 620 \mathrm{~mm} / \mathrm{min})[2]$

Fig. 2. Influence of shielding gas composition on the emission of nitrogen oxides during MIG/MAG weld brazing of steel sheets with protective coatings. $(I=70 \div 130 \mathrm{~A} ; U=13,7 \div 17,7 \mathrm{~V}$; $\left.V_{w}=3,5 \div 7,0 \mathrm{~m} / \mathrm{min} ; V_{w s}=190 \div 620 \mathrm{~mm} / \mathrm{min}\right)$
Badania emisji zanieczyszczeń pyłowych i gazowych przy lutospawaniu łukowym metodą MIG/MAG wykazały wpływ składu chemicznego gazu osłonowego na wielkość emisji pyłu całkowitego, tlenków azotu i tlenku węgla. W celu ograniczenia emisji pyłu najkorzystniejsze jest zastosowanie na osłonę łuku mieszaniny trójskładnikowej $\mathrm{Ar}+2 \% \mathrm{CO}_{2}+1 \% \mathrm{H}_{2}$. $\mathrm{Z}$ kolei mieszanina $\mathrm{Ar}+2 \% \mathrm{CO}_{2}$ pozwala na zdecydowanie największe ograniczenia wielkości emisji tlenków azotu. Najkorzystniejsze wyniki w redukcji emisji tlenku węgla można uzyskać podczas zastosowania na osłonę łuku argonu i mieszaniny $\mathrm{Ar}+2 \% \mathrm{O}_{2}$. Podobnie, jak przy procesach spawania łukowego w osłonie gazów, tak i przy lutospawaniu metodą MIG/MAG blach stalowych z powłokami nie istnieje możliwość wybrania i zastosowania gazu osłonowego o jednym uniwersalnym składzie pozwalającym na ograniczenie emisji zarówno pyłu jak i emisji szkodliwych gazów. Wpływ gazu osłonowego na emisję zanieczyszczeń związany jest z właściwościami chemicznymi, fizycznymi i energetycznymi danej mieszaniny gazowej. Argon, który jest bardzo korzystnym technologicznie gazem osłonowym do lutospawania spoiwem CuSi3Mn blach stalowych z powłokami cynkowym [4,5], w przypadku problemu emisji zanieczyszczeń do środowiska pracy, ocena tego gazu nie jest już tak jednoznacznie pozytywna. Zastosowanie argonu powoduje najwyższą emisję pyłu i tlenków azotu, ale również wprowadzenie argonu na osłonę łuku sprzyja niskiej emisji tlenku węgla. Mieszaniny z niewielką zawartością $\mathrm{CO}_{2}$ lub $\mathrm{O}_{2} \mathrm{~W}$ aspekcie technologicznym poprawiają stabilność procesu lutospawania, jakość i estetykę lutospoin $[4,5]$. Tlen i dwutlenek węgla wpływają korzystnie na stabilizację łuku elektrycznego, wprowadzanie stosunkowo małej ilości ciepła oraz zmniejszenie rozprysku. Przy lutospawaniu tlen i dwutlenek węgla mogą intensyfikować proces utleniania powłoki cynkowej na stali. W aspekcie środowiska pracy, mieszaniny te wpływają na ograniczenie emisji pyłu całkowitego oraz w przypadku mieszaniny $\mathrm{Ar}+2 \% \mathrm{CO}_{2}$ ograniczenie emisji tlenków azotu, natomiast już mieszanina $\mathrm{Ar}+2 \% \mathrm{O}_{2}$ powoduje największą emisję tlenków azotu. $\mathrm{Z}$ kolei mieszanina $\mathrm{Ar}+2 \% \mathrm{O}_{2} \mathrm{z}$ uwagi na skład chemiczny przyczynia się do znacznego ograniczenia wielkości emisji tlenku węgla. Mieszaniny dwu i trójskładnikowe z dodatkiem wodoru na poziomie $1 \div 3 \%$ technologiczne zapewniają stabilny przebieg jarzenia się łuku, brak rozprysku i dobry wygląd lutospoiny. Dodatek $\mathrm{H}_{2}$ do mieszaniny może jednakże powodować utlenienie lica lutospoiny i mieszaniny te mogą mieć niekorzystny wpływ cieplny na powłokę cynkową w strefie łączenia. W aspekcie ochrony środowiska pracy, mieszaniny trójskładnikowe argon z dwutlenkiem węgla i wodorem pozwalają na ograniczenie emisji pyłu i tlenków azotu.

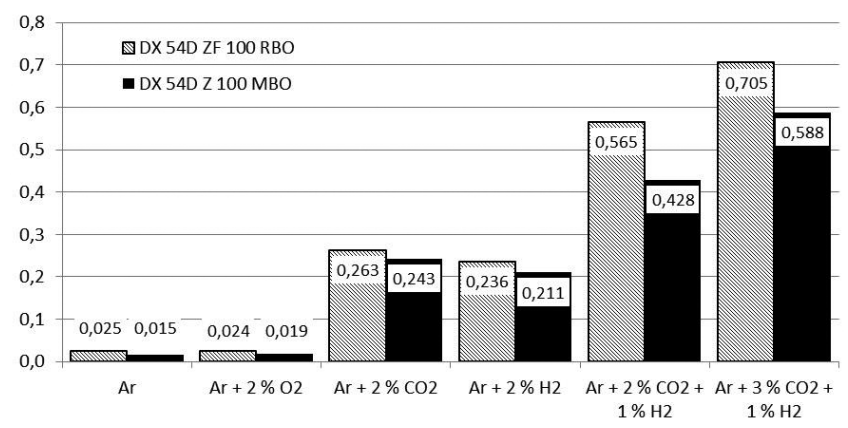

Rys. 3. Wpływ składu gazu osłonowego na wielkość emisji tlenku węgla podczas lutospawania MIG/MAG blach stalowych z powło-

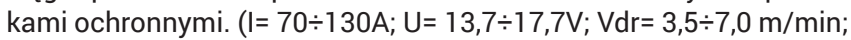
$\mathrm{Vsp}=190 \div 620 \mathrm{~mm} / \mathrm{min})[2]$

Fig. 3. Influence of shielding gas composition on the emission of carbon monoxide during MIG/MAG weld brazing of ste-

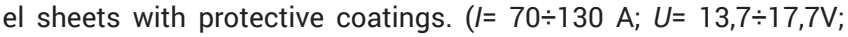
$V_{w}=3,5 \div 7,0 \mathrm{~m} / \mathrm{min} ; V_{w s}=190 \div 620 \mathrm{~mm} / \mathrm{min}$ ) 
Niestety mieszaniny z wodorem wpływają przy lutospawaniu MIG/MAG stali z powłokami cynkowymi na wzrost emisji tlenku węgla [6].

Badania wykazały, że wielkość emisji pyłu i gazów jest związana nie tylko ze składem zastosowanego gazu osłonowego, ale również zależy od rodzaju powłoki ochronnej i parametrów prądowo-napięciowych procesu [2]. Największa emisja pyłu wystąpiła przy lutospawaniu metodą MIG/MAG blach stalowych z powłoką ze stopu cynku i żelaza - powłoką typu ZF. Powłoka cynkowa typu Z charakteryzowała się mniejszymi wartościami emisji dla wszystkich badanych warunkach prądowo-napięciowych procesu i dla wszystkich gazów osłonowych (rys. 1). W przypadku emisji $\mathrm{NO}_{\mathrm{x}}$ wpływ powłoki na wielkość emisji jest trudny do jednoznacznego zdefiniowania (rys. 2), emisja $\mathrm{NO}_{\mathrm{x}}$ kształtowała się na najwyższym poziomie dla blachy z powłoką ZF przy zastosowaniu mieszanin gazowych $\mathrm{Ar}+2 \% \mathrm{O}_{2}, \mathrm{Ar}+3 \% \mathrm{CO}_{2}+1 \% \mathrm{H}_{2}$ oraz $\mathrm{Ar}+2 \% \mathrm{H}_{2}$. Natomiast przy osłonie gazowej $\mathrm{Ar}, \mathrm{Ar}+2 \% \mathrm{CO}_{2}$ i $\mathrm{Ar}+2 \% \mathrm{CO}_{2}+1 \% \mathrm{H}_{2}$ większa emisji tlenków azotu wystąpiła przy lutospawaniu stali z powłoką Z. W przypadku emisji tlenku węgla dla wszystkich badanych rodzajów gazów osłonowych większa emisja wystąpiła przy lutospawaniu blachy z powłoką typu ZF (rys. 3).

Badania wielkości emisji zanieczyszczeń przy lutospawaniu MIG/MAG wykonano dla zakresu parametrów technologicznych: natężenie prądu spawania: 70A $\div 130 \mathrm{~A}$, napięcie łuku: $13,7 \div 17,7 \mathrm{~V}$ (tabl. I). Analiza wyników badania emisji pyłu i gazów potwierdziła generalną korelację pomiędzy natężeniem prądu przy spajaniu łukowym, a wielkością emisji pyłu. Wystąpiła korelacja pełna dodatnia (związek wprost proporcjonalny), ze wzrostem wartości natężenia prądu rośnie wartość emisji pyłu, tlenków azotu i tlenku węgla. Graficzną analizę korelacji pomiędzy natężeniem prądu a wielkością emisji pyłu przy lutospawaniu MIG/MAG blachy stalowej z powłoką typu ZF przedstawiono na rysunku 4 . W przeprowadzonych badaniach przy większych natężeniach prądu przy lutospawaniu MIG/MAG występowała większa emisja pyłu całkowitego, tlenków azotu i tlenku węgla. Emisja pyłu przy lutospawaniu MIG/MAG blachy z powłoką typu ZF w osłonie $\mathrm{Ar}$ przy prądzie 130A (Ep= 4,68 mg/s) jest 1,5-krotnie większa w porównaniu do emisji pyłu przy natężenia prądu $100 \mathrm{~A}(\mathrm{Ep}=2,97 \mathrm{mg} / \mathrm{s})$ i aż 4-krotnie większa w porównaniu do emisji pyłu przy I= 70A $(\mathrm{Ep}=1,09 \mathrm{mg} / \mathrm{s})[2]$.

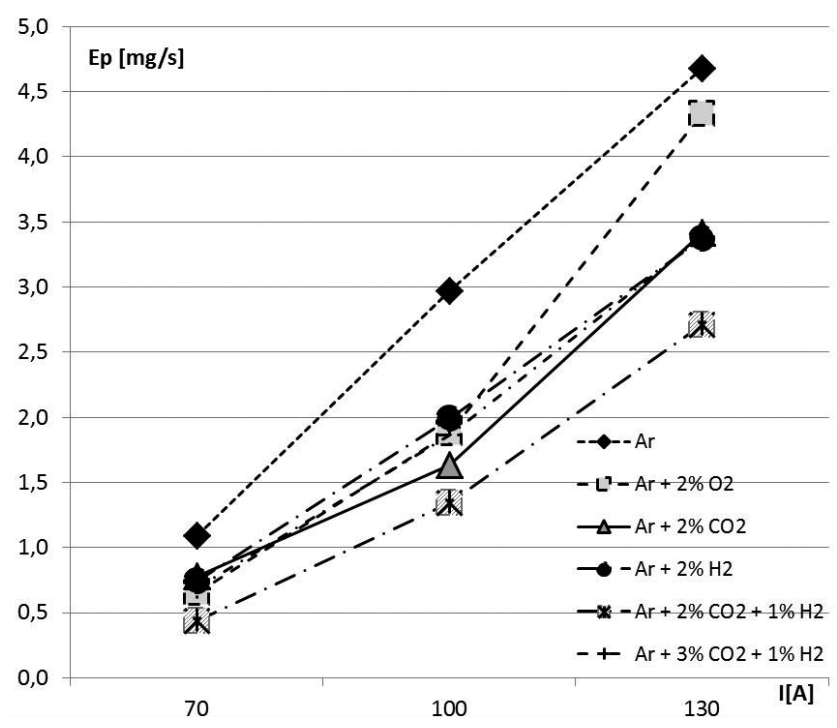

Rys. 4. Wpływ natężenia prądu na wielkość emisji pyłu podczas lutospawaniu MIG/MAG stali DX54D ZF 100 RBO w osłonie różnych gazów [2]

Fig. 4. Influence of welding current on fume emission during MIG/MAG weld brazing of DX54D ZF 100 RBO steel with protective coatings

\section{Wpływ składu gazu osłonowego na skład chemiczny pyłu przy lutospawaniu blach z powłoką cynkową}

Identyfikację oraz ilościową analizę fazową pyłu powstającego przy lutospawaniu MIG/MAG blach z zastosowaniem spoiwa CuSi3Mn wykonano dla blach z powłoką typu Z [3]. Określono następujące składniki fazowe pyłu: tlenek cynku ZnO, cynk metaliczny $\mathrm{Zn}$, miedź metaliczna $\mathrm{Cu}$, kupryt $\mathrm{Cu}_{2} \mathrm{O}$ - tlenek miedzi(I), tenoryt CuO - tlenek miedzi(II), mangan metaliczny $\gamma$-Mn (mangan o układzie krystalograficznym tetragonalnym) oraz tlenek manganu(II) $\mathrm{Mn}_{\mathrm{x}} \mathrm{O}$. Badania wykazały, że rodzaj gazu osłonowego ma istotne znaczenie dla składu fazowego pyłu oraz dla zawartości w pyle poszczególnych składników (rys. 5). Największa zawartość w pyle tlenku cynku związana jest z lutospawaniem w osłonie argonu i wynosiła 78,5\%. Najmniejsza zawartość ZnO w pyle wystąpiła dla lutospawania tradycyjną metodą MIG/MAG przy zastosowaniu mieszaniny dwuskładnikowej $\mathrm{Ar}+2 \% \mathrm{H}_{2}$ - zawartość $\mathrm{ZnO}-25,9 \%$ oraz trójskładnikowej typu $\mathrm{Ar}+3 \% \mathrm{CO}_{2}+1 \% \mathrm{H}_{2}$ - zawartość $\mathrm{ZnO}-36,4 \%$. W aspekcie zmniejszenia zawartości ZnO w pyle z procesu lutospawania korzystne jest więc zastosowanie wyżej wymienionych mieszanin gazowych. W przypadku związków pochodzących ze spoiwa; miedzi metalicznej $\mathrm{Cu}$, kuprytu $\mathrm{Cu}_{2} \mathrm{O}$ - tlenek miedzi(I) oraz tenorytu CuO - tlenek miedzi(II) ich zawartość w pyle również zależy od składu gazu osłonowego. Największe zawartości w pyle miedzi metalicznej występują dla mieszaniny trójskładnikowej $\mathrm{Ar}+3 \% \mathrm{CO}_{2}+1 \% \mathrm{H}_{2}$ i gazu $\mathrm{Ar}+2 \% \mathrm{H}_{2}$. Ograniczenie zawartości $\mathrm{Cu}$ w pyle wymaga zastosowania na osłonę łuku argonu lub mieszaniny $\mathrm{Ar}+2 \% \mathrm{O}_{2}$. Duże znaczenie dla środowiska pracy ma obecność w pyle związków manganu. Przy lutospawaniu metodą MIG/MAG wykazano w pyle obecność tylko dwóch związków manganu, był to mangan metaliczny $\gamma$-Mn (mangan o układzie krystalograficznym tetragonalnym) oraz tlenek manganu(II) $\mathrm{Mn}_{\mathrm{x}} \mathrm{O}$. Tlenek manganu(II) $\mathrm{Mn}_{\mathrm{x}} \mathrm{O}$ wystąpił $\mathrm{w}$ pyle powstającym przy zastosowaniu na osłonę łuku niektórych gazów, np. $\mathrm{Ar}+3 \% \mathrm{CO}_{2}+1 \% \mathrm{H}_{2}, \mathrm{Ar}+2 \% \mathrm{O}_{2}$ i $\mathrm{Ar}+2 \% \mathrm{H}_{2}$. Pył powstający przy lutospawaniu w osłonie argonu nie zawierał tlenku manganu (II), natomiast odnotowano zawartość manganu metalicznego $\gamma$-Mn na poziomie 3,9\%. W pyle powstającym przy lutospawaniu metodą MIG/MAG w osłonie różnych mieszanin gazowych blach z powłoką cynkową nie stwierdzono obecności związków żelaza.

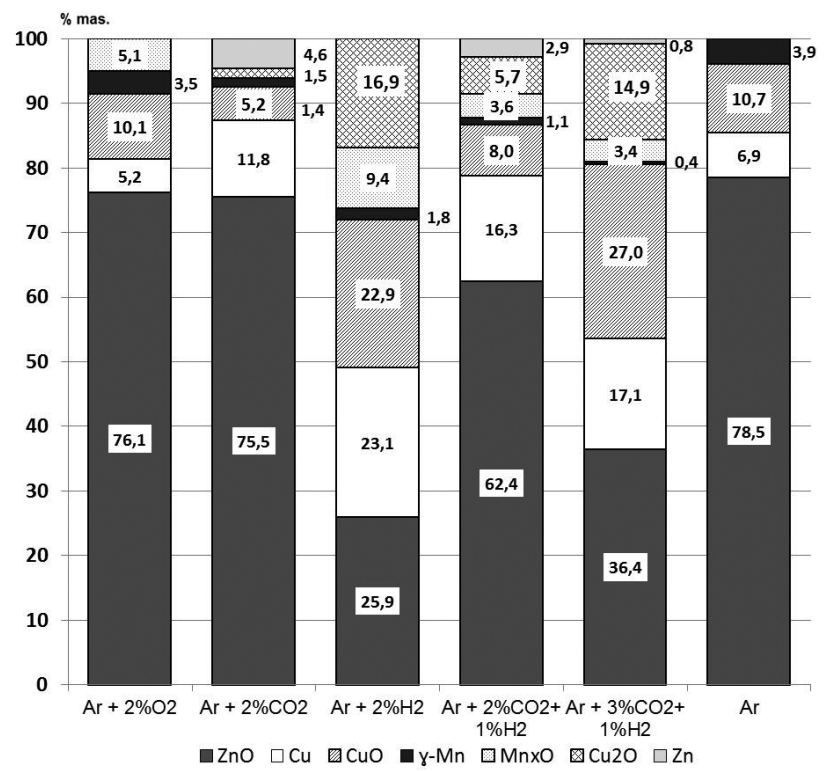

Rys. 5. Ilościowa analiza fazowa pyłu powstającego przy lutospawaniu blachy DX54D Z100MBO metodą MIG/MAG w osłonie różnych mieszanek gazowych [3]

Fig. 5. Phase analysis of fume during MIG/MAG weld brazing of DX54D Z100MBO sheet using various shielding gases 


\section{Możliwości doboru gazu osłonowego w aspekcie ograniczania \\ emisji zanieczyszczeń przy lutospawaniu łukowym}

W ocenie środowiska pracy przy procesach lutospawania łukowego istotną rolę odgrywa wielkość emisji zanieczyszczeń pyłowych i gazowych oraz skład chemiczny powstającego pyłu. Warto zwrócić uwagę, że zdecydowanie dominującym czynnikiem zagrażającym zdrowiu pracowników jest emisja pyłu i fakt wysokiej zawartości w pyle związków cynku, miedzi i obecność związków manganu. W celu zmniejszenia zawartości Zno w pyle korzystne jest zastosowanie przy tradycyjnej metodzie lutospawania MIG/MAG mieszanin gazowych $\mathrm{Ar}+2 \% \mathrm{H}_{2}$ oraz $\mathrm{Ar}+3 \% \mathrm{CO}_{2}+1 \% \mathrm{H}_{2}$. Ograniczenie zawartości $\mathrm{Cu}$ i tlenku miedzi w pyle wymaga zastosowania na osłonę łuku mieszanin dwuskładnikowych: $\mathrm{Ar}+2 \% \mathrm{O}_{2}$ i $\mathrm{Ar}+2 \% \mathrm{CO}_{2}$. Natomiast w celu redukcji emisji związków manganu jest konieczne zastosowanie w procesie na osłonę łuku mieszanin trójskładnikowych [7]. Zastosowanie mieszanin trójskładnikowych jest najkorzystniejsze w ograniczeniu wielkości emisji pyłu całkowitego.

Biorąc pod uwagę wpływ pyłu powstającego przy lutospawaniu blach stalowych z powłokami cynkowymi na organizm człowieka, dobór składu gazu osłonowego warto ukierunkować na ograniczenie właśnie emisji pyłu do środowiska pracy. W oparciu o wyniki przeprowadzonych badań dokonano oceny poszczególnych gazów osłonowych biorąc pod uwagę możliwość ograniczenia wielkości emisji zanieczyszczeń i wpływu na zmniejszenie zawartości w pyle związków cynku, miedzi i manganu (tabl. II).

Tablica II. Wpływ gazów osłonowych na ograniczenie emisji pyłu i gazów do środowiska pracy oraz na ograniczenie zawartości w pyle związków Zn, Cu i Mn przy lutospawaniu łukowym metodą MIG/MAG blach stalowych z cynkowymi powłokami ochronnymi [3] Table II. Influence of a shielding gas on the reduction of pollutant emission and Zn, Cu and Mn compound contents in fume during MIG/MAG weld brazing of zinc coated steel sheets

\begin{tabular}{|c|c|c|c|c|c|c|}
\hline \multirow[b]{2}{*}{ Gaz osłonowy } & \multicolumn{3}{|c|}{ Ograniczenie emisji } & \multicolumn{3}{|c|}{ Ograniczenie zawartości w pyle } \\
\hline & $\begin{array}{c}\text { pyłu } \\
\text { całkowitego }\end{array}$ & $\mathrm{NO}_{\mathrm{x}}$ & $\mathrm{CO}$ & $\mathrm{ZnO}$ & $\mathrm{Cu}$ i CuO & $\begin{array}{l}\text { związków } \\
\text { manganu }\end{array}$ \\
\hline $\mathrm{Ar}$ & 0 & 0 & +++ & - & 0 & - \\
\hline $\mathrm{Ar}+2 \% \mathrm{O}_{2}$ & + & 0 & +++ & 0 & + & - \\
\hline $\mathrm{Ar}+2 \% \mathrm{CO}_{2}$ & ++ & +++ & 0 & 0 & + & 0 \\
\hline $\mathrm{Ar}+2 \% \mathrm{H}_{2}$ & + & ++ & 0 & ++ & - & 0 \\
\hline $\mathrm{Ar}+2 \% \mathrm{CO}_{2}+1 \% \mathrm{H}_{2}$ & +++ & ++ & - & 0 & - & ++ \\
\hline $\mathrm{Ar}+3 \% \mathrm{CO}_{2}+1 \% \mathrm{H}_{2}$ & ++ & ++ & - & ++ & - & +++ \\
\hline
\end{tabular}

\section{Podsumowanie}

Badania emisji zanieczyszczeń pyłowych i gazowych przy lutospawaniu metodą MIG/MAG blach stalowych z powłokami cynkowymi wykazały wpływ składu gazu osłonowego na wielkość emisji pyłu całkowitego, tlenków azotu i tlenku węgla oraz skład chemiczny powstającego pyłu. Stwierdzono, że nie istnieje możliwość wybrania i zastosowania gazu osłonowego o jednym uniwersalnym składzie chemicznym pozwalającym na ograniczenie emisji zarówno pyłu jak i szkodliwych gazów oraz ograniczeniu zawartości w pyle związków cynku, miedzi i manganu. Wpływ gazu osłonowego na emisję zanieczyszczeń związany jest z właściwościami chemicznymi, fizycznymi i energetycznymi danej mieszaniny gazowej.

Przy lutospawaniu metodą MIG/MAG spoiwem CuSi3Mn blach z powłokami cynkowymi największa emisja pyłu występuje przy zastosowaniu na osłonę łuku argonu. Wprowadzanie mieszanin gazowych trójskładnikowych $\mathrm{Ar}+\mathrm{CO}_{2}+\mathrm{H}_{2}$ oraz mieszanin dwuskładnikowych $\mathrm{Ar}+\mathrm{O}_{2}$ i $\mathrm{Ar}+\mathrm{CO}_{2}$ wpływa na ograniczenie wielkości emisji pyłu całkowitego do środowiska pracy. Najkorzystniejsze wyniki w redukcji emisji pyłu można uzyskać przez zastosowanie na osłonę łuku mieszanin argon $\mathrm{z}$ dwutlenkiem węgla i wodorem, np. $\mathrm{Ar}+2 \% \mathrm{CO}_{2}+1 \% \mathrm{H}_{2}$.

Największa emisja tlenków azotu przy lutospawaniu metodą MIG/MAG występuje przy zastosowaniu na osłonę łuku argonu i mieszaniny $\mathrm{Ar}+2 \% \mathrm{O}_{2}$, natomiast wprowadzenie mieszaniny $\mathrm{Ar}+2 \% \mathrm{CO}_{2}$ pozwala na największe jej ograniczenie.

Najmniejsza emisja tlenku węgla występuje przy wprowadzaniu na osłonę łuku argonu i mieszaniny $\mathrm{Ar}+\mathrm{O}_{2}$. Mieszaniny trójskładnikowe $\mathrm{Ar}+\mathrm{CO}_{2}+\mathrm{H}_{2}$ oraz dwuskładnikowe $\mathrm{Ar}+\mathrm{CO}_{2}$ powodują wielokrotny wzrost emisji tlenku węgla w porównaniu do osłony jednoskładnikowej - argonu. 
Największa zawartość w pyle tlenku cynku związana jest z lutospawaniem w osłonie argonu i wynosiła 78,5\%. W celu ograniczenia zawartości związków $\mathrm{Zn}$ w pyle, na osłonę luku należy stosować mieszaniny dwuskładnikowe $\mathrm{Ar}+2 \% \mathrm{H}_{2}$ oraz trójskładnikowe typu $\mathrm{Ar}+3 \% \mathrm{CO}_{2}+1 \% \mathrm{H}_{2}$.

Przeprowadzone badania wykazały, że wielkość emisji pyłu i gazów przy lutospawaniu łukowym jest związana nie tylko ze składem chemicznym zastosowanego gazu osłonowego, ale również znacząco zależy od rodzaju powłoki ochronnej i parametrów prądowo-napięciowych procesu.

\section{Literatura}

[1] T. Wittczak., J. Walusiak, C. Pałczyński: Choroby układu oddechowego u spawaczy (Welding-related respiratory diseases), Medycyna Pracy 2009;60(3), s. 201-208.

[2] J. Matusiak, J. Wyciślik: Badania wpływu warunków technologicznych i materiałowych lutospawania łukowego elektrodą topliwą w osłonie gazów stali z powłokami na emisję pyłu i gazów do środowiska pracy, Praca badawcza Instytutu Spawalnictwa nr Ma-37, Gliwice (2013).

[3] J. Matusiak, J. Wyciślik: Badania wpływu składu gazów osłonowych na emisję pyłu i gazów przy lutospawaniu łukowym metodami niskoenergetycznymi blach stalowych z powłokami ochronnymi, Praca badawcza Instytutu Spawalnictwa nr Ma-38, Gliwice (2014).

[4] D.lordanescu., L.Quintino, R. Miranda., G. Pimenta,: Influence of shielding gases and process parameters on metal transfer and bead shape in MIG brazed joints of the thin zinc coated steel plates, Materials and Design 27, 2006.

[5] A. Winiowski, M. Różański, T Pfeifer: Nowe gazy osłonowe do lutospawania metodą MIG/MAG blach ocynkowanych galwanicznie, Praca badawcza Instytutu Spawalnictwa nr Ad-26/2, Gliwice 2013.

[6] J. Matusiak, J. Wyciślik: Influence of shielding gas on fume and gas emission during arc weld brazing of steel sheets with coatings". Metalurgija 54 (2015) 1, s. 71-74.

[7] J. Matusiak, J. Wyciślik, H. Krztoń: Phase analysis of fume during arc weld brazing of steel sheets with protective coatings, Metalurgija 22(2016) 2, s. 169-172 